\title{
PERSPECTIVE
}

\section{Allergic eye disease mechanisms}

\author{
J I McGill, S T Holgate, M K Church, D F Anderson, A Bacon
}

Allergic eye disease is a common ocular problem. It is one part of the whole spectrum of allergic diseases which share a common initiating mechanism and a characteristic pattern of inflammation.

The association between exposure to airborne plant pollens and the development of ocular and nasal symptoms in itself was noted by Charles Blackley in $1873 .{ }^{1}$ The classification of allergic eye diseases is based entirely on clinical features, which in the past has resulted in the use of inappropriate or unsatisfactory treatments, owing to our lack of knowledge of the underlying mechanisms. Recent work has defined such underlying pathogenic mechanisms of allergic eye disease, extending our knowledge of the cellular and mediator mechanisms involved, and enabling pathophysiological correlates to be made between the clinical patterns of disease and responses to treatment. This is now resulting in a clearer understanding of the disease processes which, in the long term, holds promise for the development of more effective treatments.

As the prevalence of allergic disease is increasing, probably through environmental factors, it is appropriate at this stage to review our current knowledge of the mechanisms of allergic eye disease.

The morbidity and mortality of asthma have increased in the past few years ${ }^{2-5}$ with no corresponding rise in the underlying rate of atopy itself. ${ }^{6}$ Environmental causes have been cited as responsible for this, as the rising trends have occurred too quickly for genetic causes to have exerted their effects. ${ }^{6}$ The increase in asthma has coincided with an increase in house dust mite levels, and is greatest in communities exposed to high allergen levels. ${ }^{2}$ However, there are no firm data available on which to base any change in the incidence of allergic eye disease.

The reported incidence rates for the different forms of allergic eye disease have been varied. This is because of geographical variations, the lack of any unequivocal objective diagnostic criteria, and difficulty over the diagnosis, particularly if not associated with other manifestations of atopy such as rhinitis, asthma, or eczema. Any rise in the incidence of allergic eye disease is at present unproved, because no epidemiological studies have surveyed all the subtypes together at any one time, so that there is no reference point from which to measure any time trends. Therefore, published incidences may not give a true indication of disease prevalence.

\section{Clinical classification of allergic eye disease (see Table 1 and Fig 1)}

Acute allergic disease ${ }^{7}$ accounts for up to $2.7 \%$ of all medical consultations seen in general practice, giving an annual rate of 51 per 1000 of the practice population. ${ }^{8}$ The milder forms of allergic eye disease have fluctuating symptoms of itch, tearing, and swelling which may be distressing but not sight threatening. Chronic forms of the disease give rise, in addition, to more severe symptoms including pain, visual loss from corneal scarring, cataract or glaucoma, and disfiguring skin and lid changes.

The signs, symptoms, and differential diagnosis of allergic conjunctivitis have recently been comprehensively reviewe ${ }^{9}{ }^{10}$ and have been classified on clinical criteria in a similar fashion by several authors (Table 1), ${ }^{10}{ }^{11}$ into the following subtypes.

(1) Seasonal allergic conjunctivitis (SAC) is the commonest and one of the mildest forms of allergic conjunctivitis. It accounts for $25 \%-50 \%$ of all cases of ocular allergy, ${ }^{7} 1012$ affects between $10 \%$ and $15 \%$ of the UK population, ${ }^{13}$ is self limiting, and is characterised by small tarsal papillae.

(2) Perennial allergic conjunctivitis (PAC) has a documented prevalence of $0.03 \%$ of the population, ${ }^{14}$ although this is likely to be an underestimate because symptoms are mild and most patients are only seen by their general practitioners and not an ophthalmologist. Symptoms persist throughout the year, with seasonal variations in up to $87 \%$ of patients, particularly in the autumn months, ${ }^{14}$ when exposure to dust mite and fungal allergens is greatest. The clinical signs and symptoms are similar to SAC, but are milder and more persistent.

(3) Atopic keratoconjunctivitis (AKC) is a more serious form of ocular allergy, with prolonged symptoms, sight threatening changes, and atopic dermatitis. ${ }^{15}$ Around 3\% of the population have atopic dermatitis, of which $25 \%-40 \%$ have some form of ocular involvement. ${ }^{16}$ Conjunctival scarring, papillae formation (with shrinking of the fornices), ${ }^{16}$ and a punctate corneal keratopathy ${ }^{15} 17$ may develop. This may progress to severe corneal epithelial disease, opacification, pannus, and superficial vascularisation. There is also an association with cataracts and keratoconus. ${ }^{16} 18$

(4) Atopic blepharoconjunctivitis (ABC) is similar to AKC but with blepharitis and no keratopathy. ${ }^{17}{ }^{18}$

(5) Vernal catarrh or vernal keratoconjunctivitis (VKC) comprises $0.5 \%$ of allergic eye disease. ${ }^{19}$ Patients are usually under 14 years of age, with males predominating over females in a ratio of $2: 1$. The condition usually resolves spontaneously by puberty, but if it does persist, the sex distribution equalises. There is a seasonal peak in incidence in spring when exposure to tree grass pollens increases, suggesting an extrinsic element in the disease. VKC is a florid condition characterised by giant papillae found in either the upper tarsal conjunctiva or at the limbus, ${ }^{20}$ the former predominating in white patients and the latter in African and Mediterranean patients. Conjunctival scarring can develop. Corneal changes vary from fine punctate erosions superiorly, enlarging to superficial ulcers with plaque formation leading to subepithelial scarring which, if it persists in the visual axis, can result in permanent amblyopia. Other characteristic features include Trantas' spots, composed mainly of eosinophils, and pseudogerontoxin. ${ }^{21}$ 
Table 1 Features of the separate types of allergic eye disease (AED)

\begin{tabular}{|c|c|c|c|c|c|c|c|}
\hline & $\begin{array}{l}\text { Seasonal } \\
\text { allergic } \\
\text { conjunctivitis } \\
(S A C)\end{array}$ & $\begin{array}{l}\text { Perennial allergic } \\
\text { conjunctivitis } \\
(P A C)\end{array}$ & $\begin{array}{l}\text { Atopic } \\
\text { keratoconjunctivitis } \\
(\text { AKC) }\end{array}$ & $\begin{array}{l}\text { Atopic } \\
\text { blepharoconjunctivitis } \\
(A B C)\end{array}$ & $\begin{array}{l}\text { Vernal } \\
\text { keratoconjunctivitis } \\
\text { (VKC) }\end{array}$ & $\begin{array}{l}\text { Giant papillary } \\
\text { conjunctivitis } \\
(G P C)\end{array}$ & $\begin{array}{l}\text { Contact } \\
\text { dermatitis }\end{array}$ \\
\hline Prevalence & $\begin{array}{l}25-50 \% \text { of } \\
\text { all AED } \\
10-15 \% \text { of } \\
\text { population }\end{array}$ & $\begin{array}{l}0.03 \% \text { of } \\
\text { population }\end{array}$ & $1.5 \%$ of population & $?$ & $\begin{array}{l}0.5 \% \text { of all AED } \\
\text { Under } 14 \mathrm{M}>\mathrm{F} \\
\text { Usually resolves by puberty } \\
\text { After this } \mathrm{M}=\mathrm{F}\end{array}$ & Iatrogenic & Not known \\
\hline Severity & Mild & Mild & $\begin{array}{l}\text { Sight threatening } \\
\text { Range moderate to } \\
\text { severe }\end{array}$ & $\begin{array}{l}\text { Not sight } \\
\text { threatening } \\
\text { Similar to AKC }\end{array}$ & Severe & Moderate & Moderate \\
\hline \multirow[t]{4}{*}{ Signs } & $\begin{array}{l}\text { Small tarsal } \\
\text { papillae }\end{array}$ & Similar less severe & $\begin{array}{l}\text { Conjunctival } \\
\text { scarring }\end{array}$ & Blepharitis & $\begin{array}{l}\text { Florid - giant papilla in } \\
\text { tarsus or limbus }\end{array}$ & $\begin{array}{l}\text { Reaction to contact } \\
\text { lens, stitches } \\
\text { prosthesis }\end{array}$ & $\begin{array}{l}\text { Skin, not } \\
\text { cornea }\end{array}$ \\
\hline & & & Papilla formation & $\begin{array}{l}\text { Similar to AKC but } \\
\text { no keratopathy }\end{array}$ & Conjunctival scarring & Florid giant papillae & $\begin{array}{l}\text { Reaction to } \\
\text { particular } \\
\text { allergen }\end{array}$ \\
\hline & & & $\begin{array}{l}\text { PAC } \rightarrow \text { Severe } \\
\text { corneal } \\
\text { opacification, } \\
\text { vascularisation }\end{array}$ & $\begin{array}{l}\text { Cataract and } \\
\text { keratoconus } \\
\text { association }\end{array}$ & $\begin{array}{l}\text { Corneal PEE develop into } \\
\text { ulcer with plaque }\end{array}$ & & Skin erythema \\
\hline & & & $\begin{array}{l}\text { Cataracts and } \\
\text { keratoconus } \\
\text { association }\end{array}$ & & $\begin{array}{l}\text { Sight threatening, Trantas' } \\
\text { spots (eosinophils) and } \\
\text { gerontoxin }\end{array}$ & & Oedema \\
\hline Seasonal & Yes & $\begin{array}{l}\text { All year round } \\
\text { with seasonal } \\
\text { variation }\end{array}$ & Sometimes & Sometimes & Yes & No & No \\
\hline
\end{tabular}

(6) Giant papillary conjunctivitis (GPC) is an iatrogenic disease associated with foreign bodies in the eye such as contact lenses, prostheses, or protruding corneal sutures, ${ }^{102}$ all of which may precipitate and perpetuate an inflammatory reaction. It is thought to have a possible allergic mechanism because of the predominance of mast cells. The increased $\mathrm{T}$ cell count is similar to that of VKC (see later), which clinically it resembles. GPC invariably resolves when the cause is removed, and keratopathy is rare. There are no published epidemiological studies of this condition.

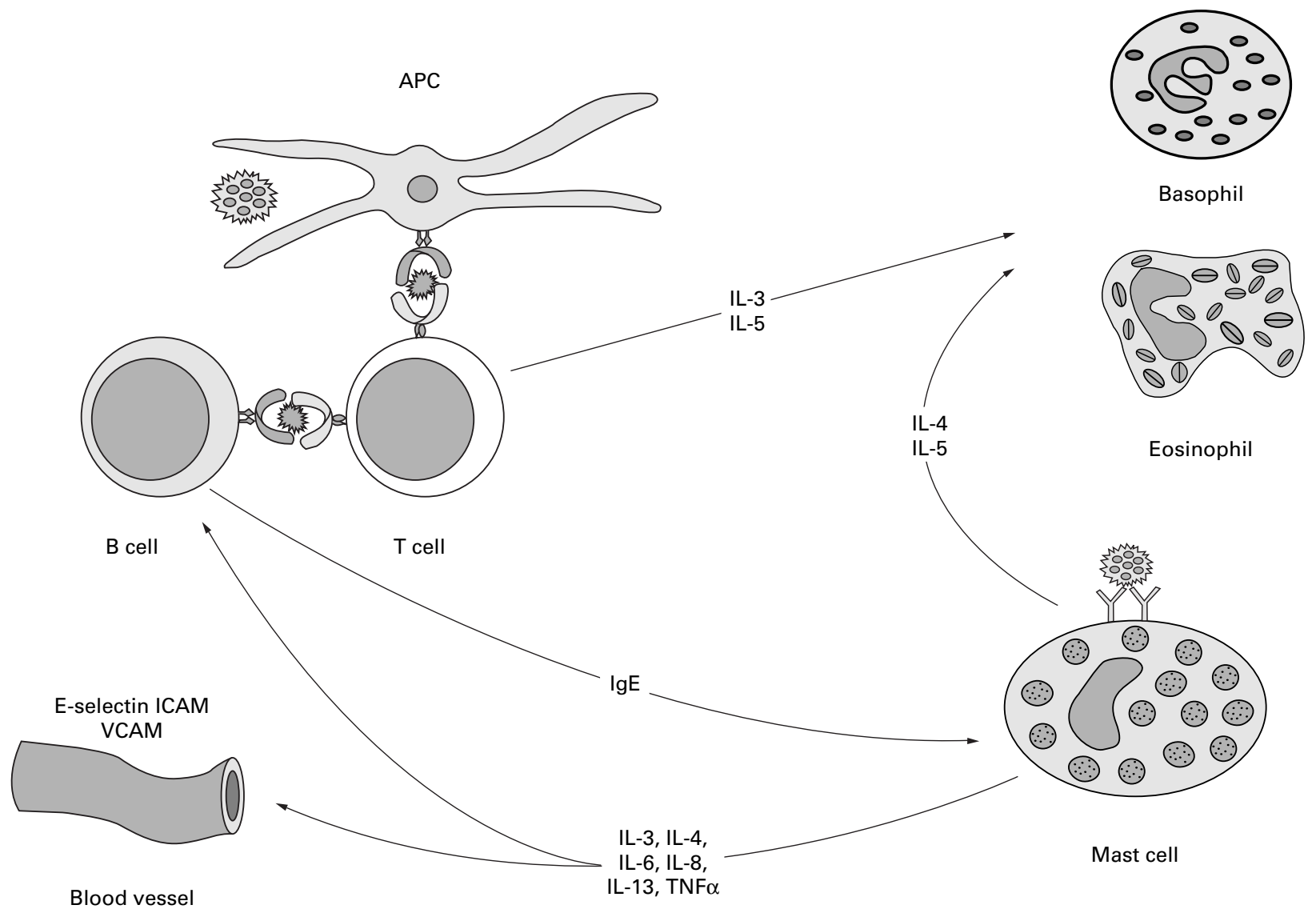

Figure 1 Cells, cytokines, and targets involved in mast cell activation. Antigen is processed by antigen presenting cells before it can be recognised by $T$ lymphocytes. These not only secrete cytokines controlling basophil, eosinophil, and mast cell activity in the orchestration of the inflammatory or allergic response, but also influence B cells to make antibody (IgE). Antigens also crosslink with membrane bound IgE on sensitised mast cells in the conjunctival epithelium and lamina propria to cause cell activation and mediator release. The consequences are the development of local inflammation and blood flow regulation seen in allergic response. Such actions are seen in $S A C$ and PAC. T cell mediated hypersensitivity reactions are seen in VKC, AKC, and GPC. APC = antigen presenting cell; E-selectin = part of selectin family; ICAM = intercellular adhesion molecule; VCAM = vascular cell adhesion molecule; TFNa $=$ tissue necrosis factor $\alpha ; I L=$ interleukin. 
(7) Contact hypersensitivity is precipitated by exposure to an allergen whose withdrawal leads to cessation of signs and symptoms. There are no epidemiological studies available. It may occur in the conjunctiva and the lid skin, as it does more diffusely in the skin in atopic dermatitis. This is a form of delayed type hypersensitivity in response to an exogenous and usually iatrogenic source, such as eye cosmetics or ocular therapeutic preparations. ${ }^{23}$

\section{Immunopathogenesis}

It is known that in acute allergic conjunctivitis there is an immunoglobulin E (IgE) mediated (type 1 hypersensitivity) response, ${ }^{24}$ while in chronic disease a mixed cell response. ${ }^{25} 26$ The evidence that different immunopathogenetic mechanisms play a part in producing the varying clinical pictures is reviewed here, together with new data from immunohistochemical and in situ hybridisation studies of the inflammatory cell populations in the conjunctiva of patients with allergic eye disease..$^{27-36}$

Immunohistochemical quantification of the cellular infiltrate in different forms of allergic eye disease has used conjunctival biopsies ${ }^{29-36}$ processed into the water miscible resin, glycol methacrylate (GMA). ${ }^{37}$ Sections of $2 \mu \mathrm{m}$ thickness were cut, and stained with a panel of monoclonal antibodies in order to accurately quantify different cell populations. By comparison of different antibodies in consecutive sections, it has been possible to colocalise specific cellular markers-for instance, for different cytokines or mast cell types in adjacent sections ${ }^{32-34}$ (see Figs $2-4$ ). The numbers of cells found in the substantia propria and the epithelium of bulbar and tarsal conjunctiva in non-atopic controls were compared with those in allergic tissue. Most of the recent advances in our knowledge of Allergic eye disease mechanisms have been based on these techniques. For a summary of the cell types, see Table 1 .

Although immediate or IgE mediated reactions are initiated by sensitised mast cells in SAC or PAC, and cell mediated hypersensitivity reactions by $\mathrm{T}$ cells in $\mathrm{AKC}$ and VKC, a similar range of cells including macrophages, neutrophils, and eosinophils, is found in both categories but in differing numbers and proportions. The cell types involved are given in Figure 1, which shows how they vary in the different types of allergic eye disease, but central to all mechanisms is the mast cell.

It has been known for some time that in allergic eye disease, conjunctival biopsies contain numerous metachromic staining mast cells. ${ }^{11}$ Using the presence of the unique neutral protease, tryptase, as an immunohistochemical marker, mast cell numbers have been found to be raised in all types of allergic disease. ${ }^{29-31}$ This suggests that IgE mediated mast cell activation contributes to all of these conditions. Following allergen challenge, tear levels of histamine, kinins, and thromboxane $\mathrm{TxB} 2$ are all elevated. ${ }^{38}$ In GPC, $30 \%$ of mast cells appear to be in a degranulated state, while in VKC this increases to $80 \% .^{39}$

In humans there exist two distinct mast cell subtypes which may be distinguished on the basis of their granule neutral protease content. ${ }^{40}$ The $\mathrm{MC}_{\mathrm{T}}$ subtype contains within the secretory granules only a single neutral protease, tryptase, while the $\mathrm{MC}_{\mathrm{TC}}$ subtype is defined by the presence of both tryptase and chymase (Figs 2 and 3). ${ }^{40}$ While both mast cell subtypes develop from the same CD34+ mononuclear precursor for its development, the $\mathrm{MC}_{\mathrm{T}}$ subtype is dependent on the presence of $\mathrm{T}$ lymphocytes, predominates at mucosal surfaces, and increases in numbers in aeroallergen driven allergic disease. The $\mathrm{MC}_{\mathrm{TC}}$ subtype appears to be independent of $\mathrm{T}$ cells, but its development requires fibroblastic derived growth factors (including stem cell factor, SCF), predomi- nates in connective and perivascular tissues, and is characteristic of fibrotic processes. ${ }^{41}$

In the normal subject, conjunctival mast cells consist predominantly of the $\mathrm{MC}_{\mathrm{TC}}$ subtype and are mainly subepithelial in distribution ${ }^{29-31} 4^{40}$ (Fig 2). MC $_{\mathrm{T}}$ numbers are moderately increased in both the epithelial and subepithelial layers in SAC and PAC ${ }^{29}$ and more so in $\mathrm{VKC}^{29} 3040$ (Fig 2). In the chronic and fibrosing conditions of $\mathrm{AKC}$ and $\mathrm{ABC}$, however, the $\mathrm{MC}_{\mathrm{TC}}$ subtype predominates, perhaps indicating an important transition from a simple mediator driven disorder to that of chronic inflammation leading to conjunctival fibrosis. ${ }^{29} 31$

IGE MEDIATED OR IMMEDIATE PHASE OF ALLERGIC RESPONSE This response (type 1 hypersensitivity) is initiated by the sensitised mast cell, which releases preformed and newly synthesised mediators in response to cross linkage by allergen to IgE bound to high affinity receptors (FceRI) on the cell surface (Figs 1 and 5). This mast cell mediated response underlies the symptomatology of SAC and PAC. Most patients have a positive family history of atopy, and raised levels of allergen specific IgE in the serum and tears. ${ }^{24}$ The seasonal nature of SAC is linked to the pattern of release of causative airborne allergens such as grass, tree, and other pollens into the atmosphere. Challenge with extracts of these allergens reproduces the signs and symptoms of the disease, providing further evidence of an IgE mediated (immediate phase) reaction. ${ }^{42}$

Recent immunohistochemical studies have shown that in SAC there is a significant increase only in the numbers of conjunctival mast cells (Fig 6), ${ }^{32} 33$ in the absence of eosinophil and neutrophil recruitment and a reduction in the number of CD8+ cells. The degree of patient symptoms correlates with mast cell numbers present. ${ }^{34}$

The cellular profile of PAC is similar to SAC but more pronounced in magnitude (see Fig 6). In a recent study, the principal allergen was identified as the house dust mite Dermatophagoides pteronyssinus, $78 \%$ having mite specific IgE in their tears. ${ }^{14}$ Severely atopic patients with atopic dermatitis, AKC, and asthma, frequently have greatly elevated circulating levels of IgE, although there is no good correlation between disease activity and total IgE levels. ${ }^{43}$ Finally, in VKC, IgE and other antibodies to grasses have been demonstrated in the tears. ${ }^{44}$

ROLE OF MAST CELL MEDIATORS IN THE IMMEDIATE ALLERGIC REACTION

The pro-inflammatory mediators released by mast cells include histamine, leukotriene $\left(\mathrm{LTC}_{4}\right)$, prostaglandin $\left(\mathrm{PGD}_{2}\right)$, tryptase, chymase, carboxypeptidase $\mathrm{A}$, cathepsin $\mathrm{G}$, platelet activating factor (PAF, a powerful eosinophil chemotactic agent), and other eosinophil and neutrophil chemoattractants. ${ }^{46}$ The acute inflammatory response may also induce the influx of neutrophils and eosinophils into the conjunctiva. Allansmith and Ross ${ }^{47}$ reported high numbers of neutrophils, while others have found high levels of neutrophil chemoattractants. ${ }^{48}$

Mast cell activation leads to the release of mediators into tears which are responsible for the symptoms of allergic eye disease. It has been shown that conjunctival allergen challenge produces an early phase allergic response (EPR), followed by a dose dependent late phase response (LPR) ${ }^{38}$ In atopic patients challenged with mixed grass extract, the EPR with oedema itching and tearing was maximal at 20 minutes when there was a significant increase in tear histamine and tryptase levels. ${ }^{36}$ This reduced to normal by 40 minutes, suggesting that mast cells may be responsible for this phase. At 6 hours, symptoms increased, with a second peak of tear histamine and eosinophil cationic protein levels but not tryptase, with few basophils present suggesting 

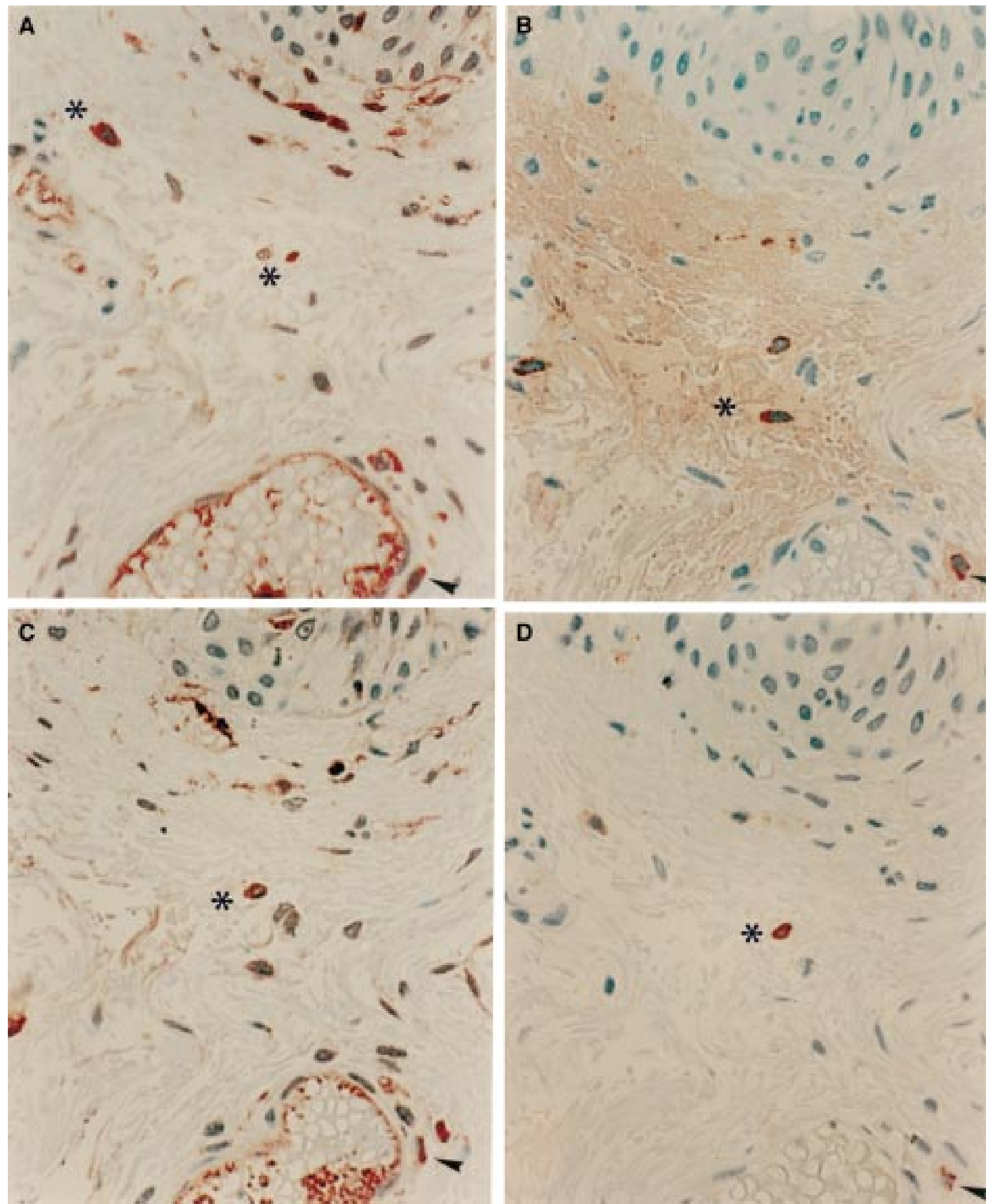

Figure 2 To show neutral proteases in sequential sections in bulbar conjunctiva from seasonal allergic conjunctivitis (SAC). (A) GE-C in bulbar conjunctiva of $S A C$ sequential section. (B) AA1 in bulbar conjunctiva of $S A C$ sequential section. (C) CPA in bulbar conjunctiva of SAC sequential section. (D) Chymase in bulbar conjunctiva of $S A C$ sequential section. $C E-C=$ cathepsin- $G$ polyclonal antibody; $A A 1=$ antitrypsinase monoclonal antibody; CPA = carboxypeptidase monoclonal antibody. Example of stained cell marked with an asterisk.

that mast cells were responsible for this phase, and were degranulating and so refractory to tryptase. ${ }^{36}$ The conjunctival cellular infiltrate contained mast cells, neutrophils, eosinophils, and macrophages, but few CD4+ or CD8+ T cells. ${ }^{36}$ Tissue adhesion molecules E-selectin and ICAM-1 levels were significantly increased at 6 hours, explaining conjunctival recruitment of granulocytes, especially neutrophils. Significantly raised levels of tear eosinophil cationic protein (ECP) were detected at 6 hours providing evidence for the selective recruitment of eosinophils into the conjunctiva. ${ }^{36}$ VCAM-1 levels were also increased at 6 hours, explaining the influx of eosinophils during the late phase reaction, ${ }^{36}$ its implication in the genesis of inflammation seen in SAC, and in the prolonged forms of allergic eye disease such as in AKC or VKC. Immunohistochemical analysis of the cellular response 6 hours after allergen 

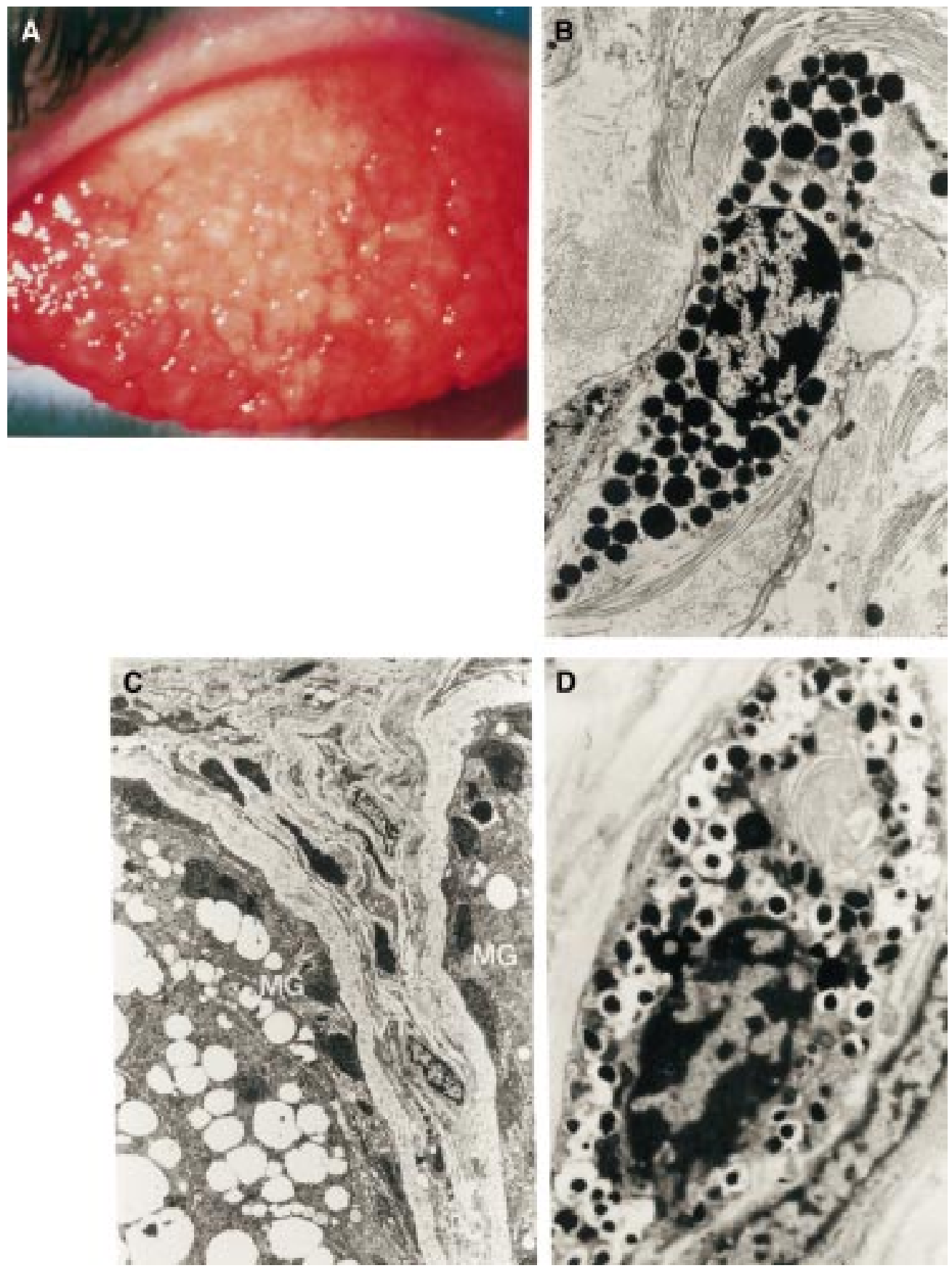

Figure 3 To show clinical picture of giant papillary conjunctivitis (GPC) and cells involved. (A) Giant papillae in GPC, upper tarsal lid. (B) Electron microgram, tarsal substantia propria between meibomian glands are fine vertical tufts that run up to the surface of the epithelium and are filled with inflammatory cells in response to the allergic reaction producing papillae. (C) Mast cell, granulation, intact. (D) Mast cell, degranulated.

challenge demonstrated degranulated mast cells, increased numbers of both neutrophils and eosinophils, but no increase in the number of $\mathrm{CD} 4+$ or $\mathrm{CD} 8+\mathrm{T}$ lymphocytes. ${ }^{36}$ The presence of granulocytes is accounted for, at least in part, by the preceding action of mast cells and the release of mast cell autocoids and cytokines.

Recent work has demonstrated an additional role for the conjunctival mast cell in the ocular allergic response. It has been shown that mast cells store and release the pro-inflammatory cytokines ${ }^{46}$ including IL-4, IL-5, IL-6, IL-8, IL-13, and tumour necrosis factor $\alpha(\mathrm{TNF} \alpha){ }^{46}{ }^{48-51}$ The two types of mast cell present in the conjunctiva (the $\mathrm{MC}_{\mathrm{tc}}$ phenotype predominating in normal conjunctiva, the $\mathrm{MC}_{\mathrm{t}}$ in allergic conjunctiva) (see earlier) are heterogeneous with respect to cytokine storage. ${ }^{32}$ In SAC, IL-4, and IL-13 are predominately localised to $\mathrm{MC}_{\mathrm{tc}}$ cells, IL-5 and IL-6 to $\mathrm{MC}_{\mathrm{t}}$ cells. $^{32-34}$

The functional significance of these cytokines is exemplified by IL- 4 which is an essential mediator of the allergic response, inducing the switching of B cells from IgM to IgE production ${ }^{49}$ (Fig 4 ). It promotes $\mathrm{T}$ cell growth, directs $\mathrm{T}$ helper cell (TH-2) differentiation essential to the allergic reaction, and is obligatory for the expression of the IL-4 gene cluster on chromosome 5, which includes IL-3, IL-4, IL-5, IL-13. ${ }^{52} 53$

Immunocytochemistry has shown that there are two types of IL-4 present, one form contained in granules throughout the whole cytoplasm and one confined to the cell membrane ${ }^{33}$ (Fig 4). The former is thought to be the stored form, and is present in out of season SAC patients. 

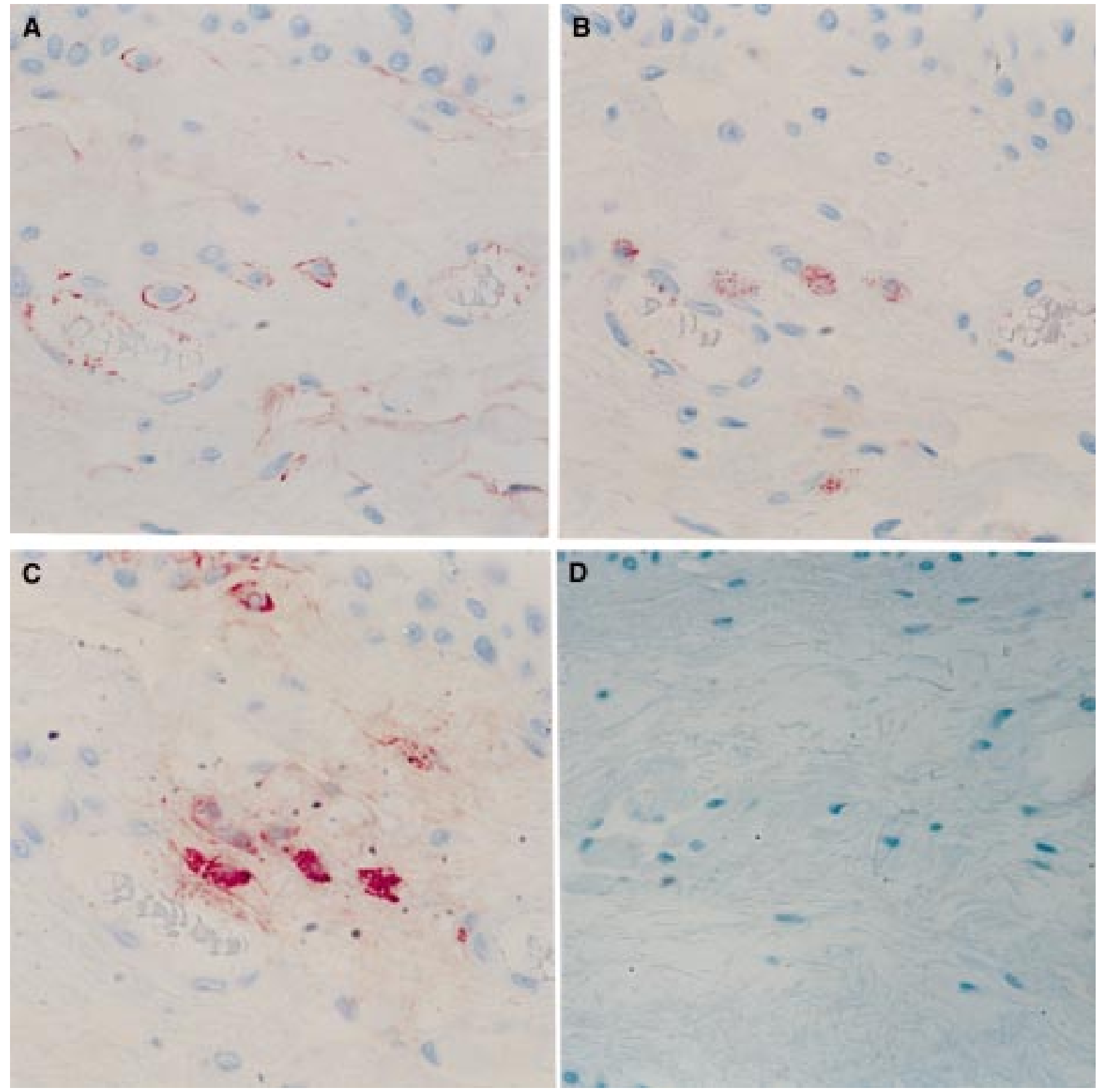

Figure 4 To show in sequential $2 \mu \mathrm{m}$ sections of bulbar conjunctiva from a patient with atopic keratoconjunctivitis, the IL-4 found in mast cells of both types $M C_{T C}$ and $M C_{T}$, and how IL-4 is colocalised to mast cells by means of using different stains in sequential sections, to identify the mast cell and the next section IL-4. (A) MAB 3H4 for secreted form of IL-4 showing ring pattern. (B) AA1, antitrypsinase MAB to mast cell showing granular stain in $M C_{T}$ type of mast cell. (C) Chymase $M A B$ to show $M C_{T C}$ mast cell. (D) IgG, negative control.

The latter is present in increased amounts with a different immunohistochemical characteristic, and is found in active SAC. ${ }^{33}$ Not only is Il-4 stored in mast cells, but by using riboprobes to IL-4 mRNA, in situ hybridisation techniques have demonstrated that IL- 4 is also manufactured in the mast cell (Anderson, personal communication).

IL-5, a growth and differentiation factor for eosinophils and a chemoattractant and priming agent for these cells, ${ }^{52}$ is localised to the $\mathrm{MC}_{\mathrm{t}}$ mast cell in SAC. ${ }^{32}$ In SAC, Il-6 which augments $\mathrm{T}$ and $\mathrm{B}$ cell function, and potentiates IL-4 synthesis of $\mathrm{B}$ cells, is also localised to the $\mathrm{MC}_{\mathrm{t}}$ mast cell phenotype. ${ }^{33} \mathrm{TNF} \alpha$, a potent priming agent for mediator secreting cells and upregulation of endothelial cell adhesion molecules, ${ }^{51}$ is also present in conjunctival mast cells, but is not significantly increased in SAC. ${ }^{33}$

Mast cell growth and maturation depends on the presence of cytokines and growth factors, of which stem cell factor (SCF) is the primary regulator. SCF, which also enhances IgE dependent mast cell mediator release and cytokine generation and release, is a chemoattractant for mast cells. ${ }^{54}$ Using the techniques of in situ hybridisation, immunohistochemistry, and reverse transcriptase polymerase chain reaction (RT-PCR), for the first time anywhere in the body it has been shown that both conjunctival mast cell phenotypes not only store but also manufacture SCF, with a fourfold increase in SAC. ${ }^{55}$ Thus the mast cell has the potential to control its own growth and activity.

As mast cells are an important source of multifunctional cytokines in allergic eye disease, this enables them to have a central role in the disease mechanism, their degranulation leading not only to "the immediate symptoms of SAC, but through the $\operatorname{IgE}$ dependent release of stored cytokines, to a rapid upregulation of conjunctival inflammation in all forms of ocular allergy". ${ }^{33}$

Other conjunctival cells also contribute to the disease process, one of which is the eosinophil. It is a powerful 


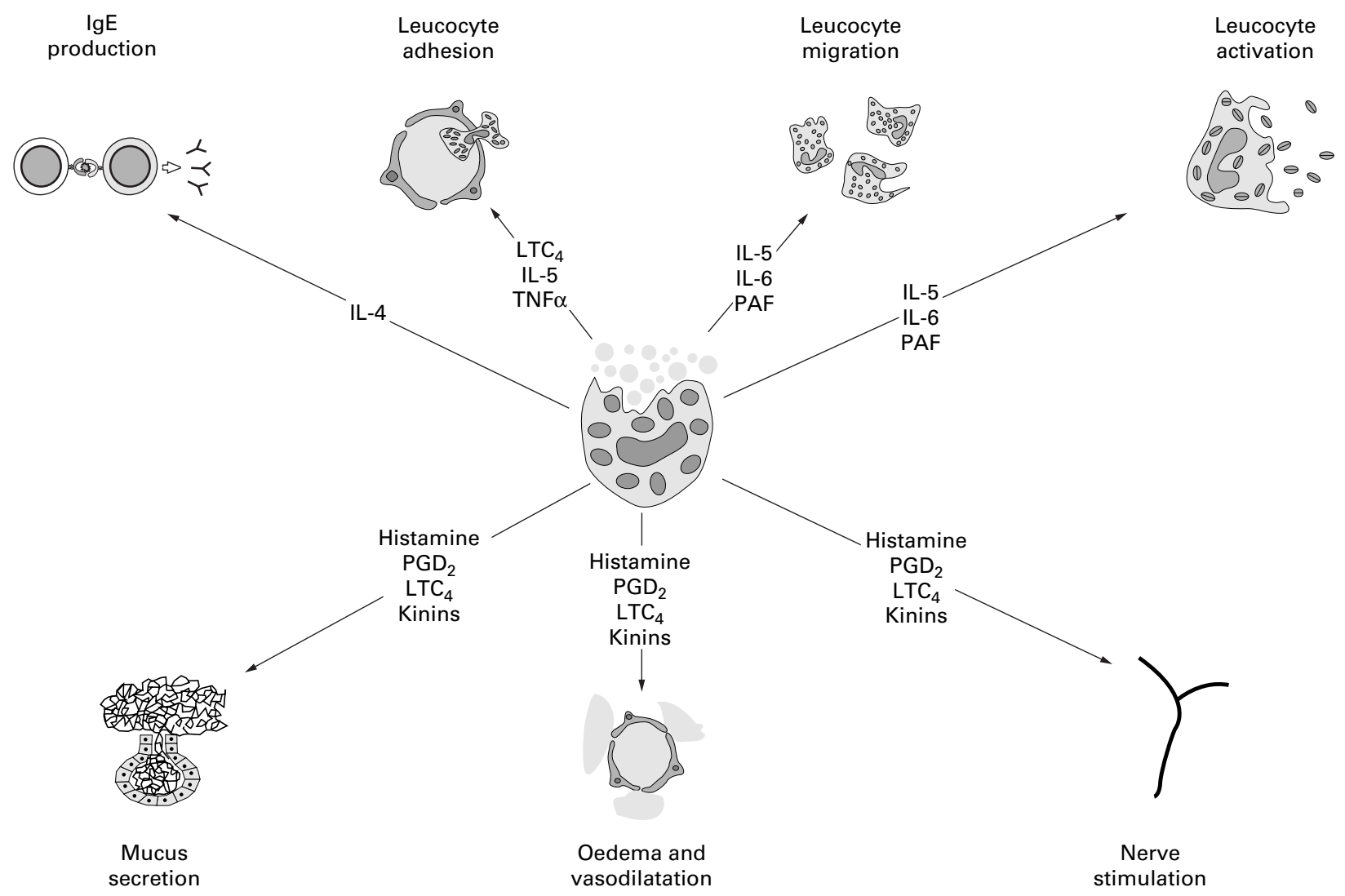

Figure 5 Profile of products released from activated mast cells and their suggested mechanism(s) of action. (See also key to Fig 1.) PGD ${ }_{2}=$ prostaglandin; $L_{T} C_{4}=$ leukotriene $P A F=$ platelet activating factor.

effector cell, releasing arginine rich toxic proteins capable of causing corneal epithelial damage. These include major basic protein (MBP), ECP, and eosinophil derived neurotoxin, EDN. ${ }^{56}{ }^{57}$ However, while its presence is strongly indicative of allergic eye disease, its absence on conjunctival scrape cytology does not preclude the diagnosis. ${ }^{58}$ In the normal conjunctiva, eosinophils are not normally found in the epithelium of non-atopic subjects ${ }^{58}$ and rarely in the deeper layers, but numbers are increased in $\mathrm{AKC},{ }^{17}$ and to a greater degree in VKC, both in the conjunctival epithelium, subepithelium, and tears..$^{59}$ Eosinophil granule derived proteins have been immunolocalised to the base of vernal ulcers. ${ }^{57}$

These observations provide strong evidence of a role for the eosinophil in allergic eye disease. In SAC, in studies during the pollen season or following allergen provocation, eosinophils have been found to infiltrate the conjunctiva but return to normal levels out of season. ${ }^{32}$ Their contribution to the inflammatory response is suggested by this increase.

INFLUENCE OF STEROID HORMONES ON INFLAMMATORY CELLS It is known that both androgens and oestrogens can exacerbate the clinical and histopathological manifestations of allergic conjunctivitis. ${ }^{6061}$ Thus, the demonstration that sex hormone receptors are present on most inflammatory cells $^{62}$ and, in particular, on eosinophils ${ }^{63}$ is of considerable interest. A recent study of $\mathrm{VKC}^{64}$ has shown that eosinophils form $70 \%$ of cells expressing oestrogen and progesterone receptors in both tarsal and bulbar conjunctiva sections. The observation that up to $30 \%$ of oestrogen and progesterone receptor expression was on cells other than eosinophils raises the possibility that other inflammatory cells may also be influenced by these hormones. ${ }^{64}$ The functional expression of steroid receptors might explain VKC predominance in prepubertal children, the decreas- ing incidence of VKC with puberty after which there is equal distribution between males and females, and the decline in prevalence of VKC with age. ${ }^{10}$

T CELL MEDIATED HYPERSENSITIVITY IN ALLERGIC EYE DISEASE

The normal human conjunctival epithelium is populated by $\mathrm{CD} 4+$ and $\mathrm{CD} 8+\mathrm{T}$ cells, mainly in the subepithelium..$^{27}$ In the active forms of SAC and PAC, the $\mathrm{T}$ cell repertoire remains virtually unchanged when compared with the normal (Figs 7 and 8). ${ }^{32}{ }^{33}$ However, in chronic allergic disorders (AKC, VKC, GPC, but not $\mathrm{ABC}), \mathrm{CD} 4+\mathrm{T}$ cells but not CD8+ $\mathrm{T}$ cell numbers are increased, ${ }^{27}$ with a mixed cellular infiltrate containing many mast cells, eosinophils, neutrophils, and macrophages $^{16-27}$ (Figs 7 and 8).

In chronic allergic diseases non-IgE mechanisms contribute to the immunopathological mechanism. ${ }^{16}$ For instance, in VKC and GPC there is no clear cut difference between the allergen specific IgE responses and the nature and severity of the allergic responses, ${ }^{44}$ hence it is likely that cell mediated responses are involved.

In the normal conjunctiva, most of the $\mathrm{T}$ cells are naive, but in the chronic allergic conditions, especially AKC, VKC, GPC, when there is an increase in CD4 cell population, $90 \%$ of the $\mathrm{T}$ cells are memory $\mathrm{T}$ cells. ${ }^{27}$ Together with this rise of activated $\mathrm{T}$ cells (activated \{HLA$\mathrm{DR}\} \mathrm{CD} 4+$ memory $\{\mathrm{CD} 45 \mathrm{RO}+\} \mathrm{T}$ cells $)$, there is a corresponding upregulation of markers present on antigen presenting cells. ${ }^{27}$ The type of $\mathrm{T}$ cells in AKC and ABC is different from that in VKC and GPC $(50 \%$ of $\mathrm{T}$ cells in VKC and GPC co-expressed CD45RO and CD4RA, but this was rare in $\mathrm{AKC}$ and $\mathrm{ABC}^{27}$ ). This suggests in $\mathrm{AKC}$ and $\mathrm{ABC}$, both associated with systemic atopy, that $\mathrm{T}$ cells may be recruited from circulating specific memory $\mathrm{T}$ cells, whereas in VKC and GPC $\mathrm{T}$ cells are produced locally. ${ }^{27}$ 


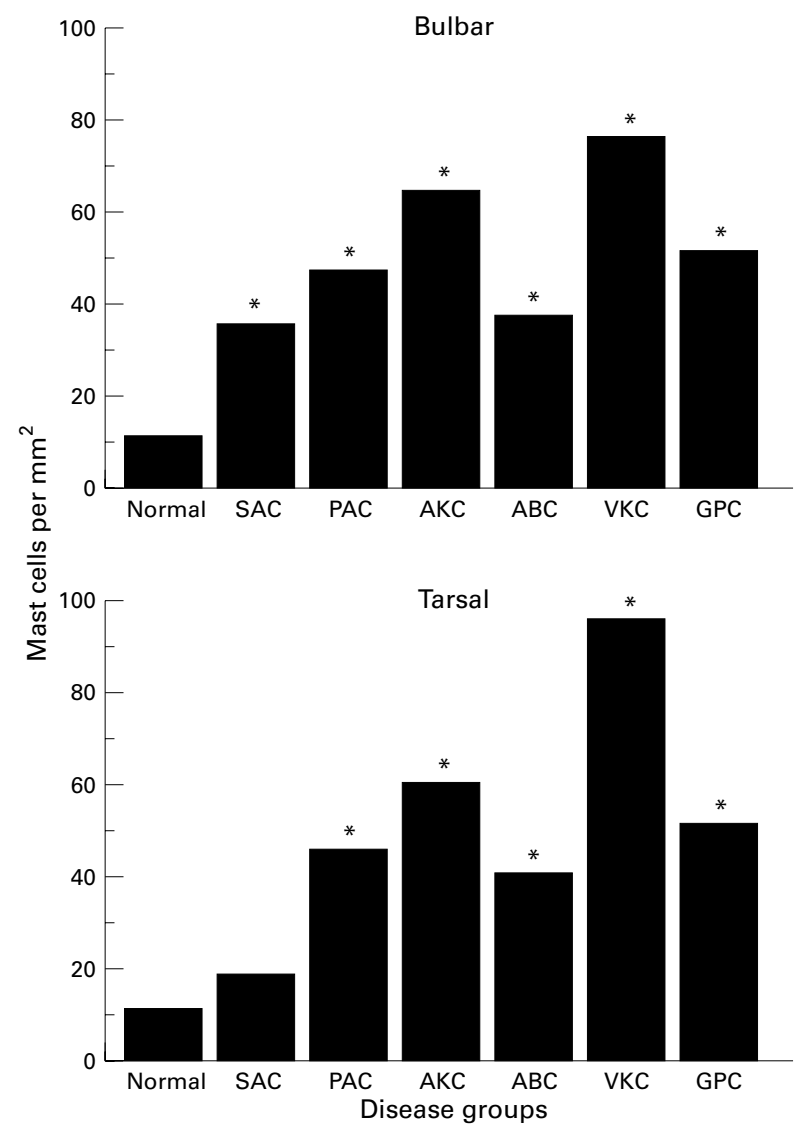

Figure 6 To show the concentration of epithelial and subepithelial mast cells in the different types of allergic eye disease in both tarsal and bulbar conjunctiva. (From Baddeley et al. ${ }^{29}$ By kind permission of the publisher of the fournal of Allergy and Clinical Immunology.)

In addition to classifying lymphocyte subsets with respect to their $\mathrm{T}$ cell receptors, such as $\mathrm{CD} 4+$ and $\mathrm{CD} 8+$, they may also be classified by the profile of cytokines that they generate and secrete.

Studies originally performed in the mouse have shown the presence of two distinct CD $4+\mathrm{T}$ cell subsets. ${ }^{65}$ The first designated TH-1 cells produce IL-2, IL-3, TNF $\beta$, and interferon $\gamma$ (IFN $\gamma$ ), and are more closely associated with the cell mediated reaction (classic delayed type hypersensitivity). The second, TH-2 cells, produce a range of cytokines encoded on chromosome 5 including IL- 4 and IL-5, which promote immediate hypersensitivity responses through their ability to stimulate proliferation, B cell IgE production, and eosinophil production, activation, and survival. ${ }^{656}$ To help determine the mechanisms of allergic eye disease, the cytokine profile of $\mathrm{T}$ lymphocytes in conjunctival biopsies has been determined by in situ hybridisation, ${ }^{28}$ a technique which demonstrates the presence of product specific messenger RNA within a cell. Early results have shown that in AKC there are increased numbers of both $\mathrm{TH}-1$ and $\mathrm{TH}-2$ type lymphocytes, and that in VKC, only cells positive for IL-3, IL-4, and IL-5 mRNA are found, which are typical of the TH-2 phenotype. This suggests that VKC results from a maturation shift of CD4+ T cells towards a pattern of cytokines which drives a mast cell and eosinophil mediated inflammatory response. ${ }^{28}$

\section{ROLE OF ADHESION MOLECULES IN ALLERGIC EYE DISEASE}

MECHANISMS (SEE FIG 1)

Adhesion molecules expressed on blood vessel endothelial cells and leucocytes arrest the passage of circulating leucocytes in areas of inflammation. This is achieved by

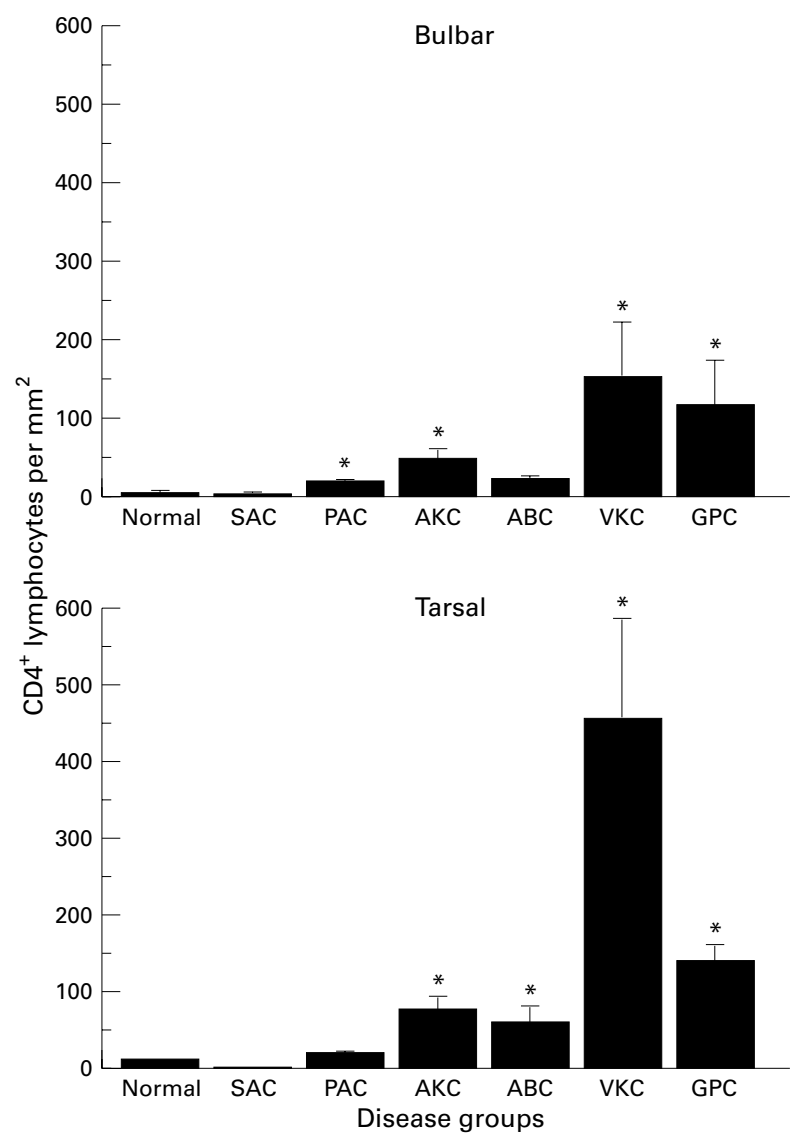

Figure $7 \quad C D 4+T$ cell numbers in substantia propria in allergic conjunctivitis. (From Metz et al, ${ }^{27}$ Anderson et al, ${ }^{32}$ and MacLeod et al ${ }^{33}$.)

adhesion molecule ligand interactions that cause leucocytes to adhere to the vascular cell wall, followed by their transendothelial migration to the site of active inflammation.

We have found correlations between the levels of expression of the adhesion molecules E-selectin, intercellular adhesion molecule-1 (ICAM-1), and vascular cell adhesion molecule-1 (VCAM-1), and the different cell types found in the inflammatory infiltrate of allergic eye disease. ${ }^{35}$ In the normal conjunctiva there is a basal expression of all adhesion molecules, while in allergic eye disease these levels are increased. ICAM-I and E-selectin are expressed in 40-78\% of vessels in SAC and PAC, and 90\% in VKC. ${ }^{35}$ In SAC, biopsies taken out of season demonstrated a marked reduction in all three CAM levels, almost to normal. VCAM-1 levels were elevated in all forms of allergic eye disease, but were highest in VKC. ${ }^{35}$ There was a positive correlation between ICAM and E-selectin levels and the degree of granulocyte and lymphocyte infiltrate, whereas VCAM expression correlated with eosinophil levels. ${ }^{35}$ This suggests that it is the relative concentration rather than any selective adhesion molecule association that results in the specific patterns of leucocyte recruitment. ${ }^{35}$ This explains why VCAM-1, under the specific influence of IL-4, is most selectively and strongly expressed in VKC, ${ }^{35}$ but not after allergen challenge in SAC out of season. This is consistent with the demonstration in VKC of the high numbers of CD4+ cells and eosinophils present (both of which bear its integrin ligand VLA-4), with presumably a strong IL-4 signal which is produced by $\mathrm{TH}-2$ cells.

To account for the different forms of allergic eye disease, a mechanism is thus provided with the selective cell recruitment of cells and subsequent mediator release. The 


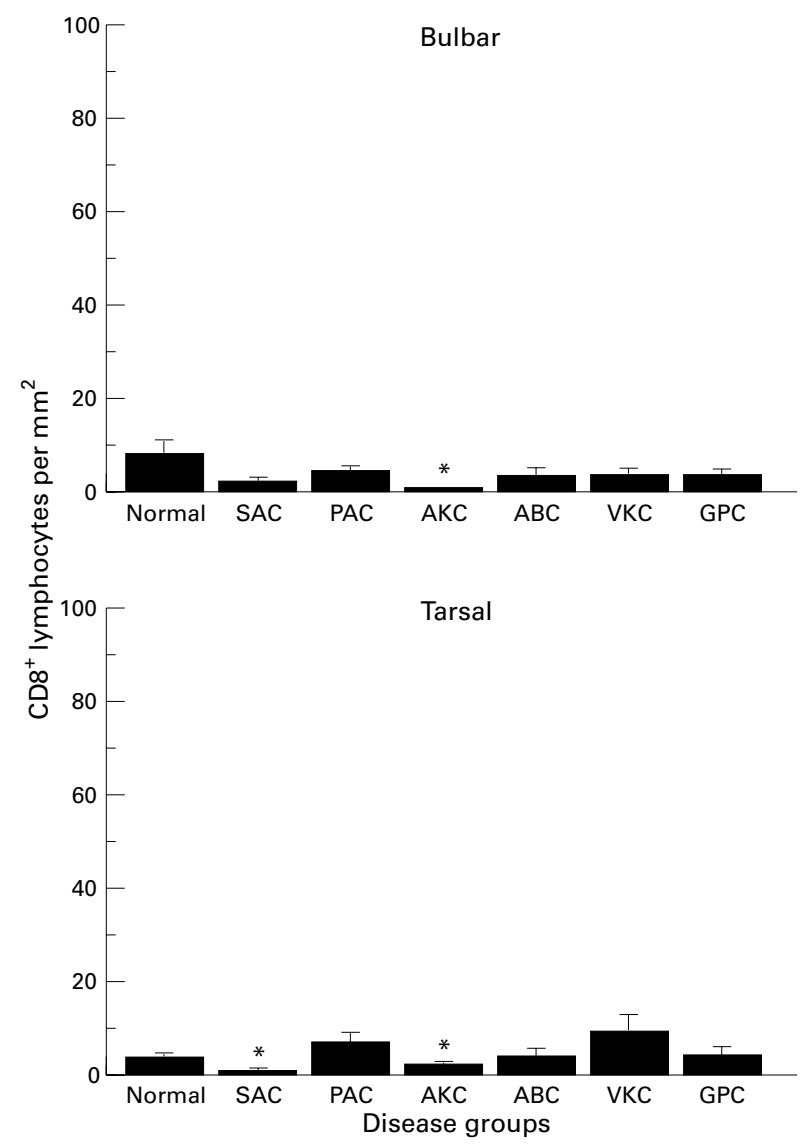

Figure 8 CD8+ T cell numbers in substantia propria in allergic conjunctivitis. (From Metz et al, ${ }^{27}$ Anderson et al, ${ }^{32}$ and MacLeod et al ${ }^{33}$.)

mast cell is central to this process, inducing different adhesion molecule expression in the acute phase, and with continued activation, generating increased adhesion molecule expression.

\section{OTHER FACTORS CONTRIBUTING TO THE INFLAMMATORY} CONJUNCTIVAL RESPONSE

Corneal sutures, deposits, and filtering blebs have been implicated in causing GPC. These abnormalities have in common an abrasive surface against which the tarsal conjunctiva rubs with blinking. In addition to $\operatorname{IgE}$ cross linkage, mast cells are also known to degranulate in response to a range of different stimuli, including the neuropeptides, substance $\mathrm{P}, \mathrm{VIP}$ somatostatin, ${ }^{67}$ and the complement fragments $\mathrm{C} 3 \mathrm{a}$ and $\mathrm{C} 5 \mathrm{a} .{ }^{68}$ Thus alternative mechanisms may be postulated for the initiation of mast cell driven disease. Concurrent infection with staphylococci ${ }^{69}$ is common in AKC. The role of toxins produced by staphylococci in producing keratopathy has not been confirmed, but the blepharomeibomianitis contributes to the symptomatology of those with atopic dermatitis and AKC. In addition, there is evidence that staphylococcal cell wall products may also induce mast cell degranulation in vitro. ${ }^{70}$

\section{Conclusions}

The atopic genotype may manifest itself in phenotypes of varying severity in the eye, as in other organs, hence the different clinical types of allergic eye disease. There are numerous parallels and differences between allergic eye diseases and allergic manifestations in other organs, such as the airways and the skin, which may help us to elucidate the molecular and cellular processes of ocular immunopathology. While perennial rhinitis, for example, which occurs in association with PAC, appears to be mast cell driven, ${ }^{71}$ in the more chronic conditions such as atopic dermatitis and asthma which, like AKC and VKC, have an appreciable morbidity, CD4+ T lymphocytes and eosinophils play an important role. ${ }^{72}$ However, what is not understood at present is the variable incidence of and relative importance of the TH-2 type response, which occurs both in VKC and GPC, in allergic and non-atopic allergic eye disease. Further research could focus on the cause of the apparent functional differences of CD4+ cells in AKC, associated with atopic dermatitis and asthma, and VKC, in which other factors, such as the overexpression of sex hormone receptors, may also play a role.

\section{Treatment options and regimens}

Now that the cellular infiltrates in both acute and chronic disease are better characterised, there are significant implications for treatment of allergic eye disease (for review see Abelson and Schaefer ${ }^{73}$ ).

Topical therapy is the preferred treatment in mild diseases of SAC and PAC. Since neither are life threatening, or even sight threatening, experimental systemic treatments are not indicated in the way they may be in more serious ocular allergic disease such as AKC. Powerful anti-CD4+ $\mathrm{T}$ cell agents, such as cyclosporin, should be kept for severely affected cases with keratopathy. In the $\mathrm{T}$ cell driven processes of $\mathrm{VKC}$ and $\mathrm{AKC}^{27} 28$ specific anti-TH-2 treatment of VKC, rather than blanket anti-T cell therapy, may be a future option.

In SAC and PAC, where mast cells and histamine release are involved in the disease pathogenesis, both topical and systemic therapies have been tried. Oral histamine $\mathrm{H}_{1}$ receptor antagonists (antihistamines) such as astemizole, terfanidine, and loratidine have been shown to be effective, ${ }^{74}$ but they are not ideal because they take several hours to act and may have some systemic side effects such as sedation. Terfenadine, which inhibits release of histamine (and prostaglandin from mast cells) can also interact with other drugs, especially erythromycin and other macrolides. ${ }^{75}$

Topical treatment offers several obvious advantages. Eye drops are easily applied and seldom lead to systemic side effects. Also, the physical presence of the drops themselves will have a washout effect, helping to remove the inflammatory mediators and thereby lessening some of the symptoms. Topical treatment may also have some disadvantages. Vasoconstrictor drops only act for a short time and can lead to a rebound vasodilatation. Topical steroids are effective in reducing the influx of inflammatory cells but have little effect on mast cell mediator secretion, are slow to act and take several days to achieve their maximal effect. They may also have serious side effects, such as producing glaucoma, causing cataracts, and potentiating infection, and so should not be used routinely in these conditions.

Mast cell stabilisers, such as sodium cromoglycate, the only one available for many years, are most effective in SAC and PAC and carry very few side effects, but patients need to receive treatment for several days before the expected exposure to allergen reducing the tryptase and inflammatory cells after allergen challenge. New quicker acting and more efficacious agents are now available. One of these is lodoxamide ${ }^{76}$ which acts to reduce tear tryptase and inflammatory cells after allergen challenge. ${ }^{77}$ In a comparative trial with sodium cromoglycate in subjects with $\mathrm{AKC}, \mathrm{VKC}$, and GPC, it was found to be superior in terms of symptom relief, ${ }^{78}$ and to be effective in the long term treatment of VKC, ${ }^{79} 80$ especially in cases where an epitheliopathy exists. ${ }^{81}$ There is no published evidence of the effectiveness of lodoxamide in SAC and PAC, although it is 
promoted for these conditions! Nedocromil sodium is another new generation mast cell stabiliser. In experiments in vitro, it was at least significantly more potent than cromoglycate in inhibiting mast cell histamine release induced by anti-human IgE, ${ }^{82-84}$ and more potent than cromoglycate on eosinophil ${ }^{85} 86$ and macrophage activation. $^{87} 88$ In placebo controlled trials, nedocromil sodium has been found to be effective in the treatment of SAC, ${ }^{89}{ }^{90} \mathrm{PAC}^{91}{ }^{91} \mathrm{GPC},{ }^{92}$ and VKC, ${ }^{93}{ }^{94}$ and compared with sodium cromoglycate, superior in $\mathrm{SAC}^{95}$ and VKC. ${ }^{94}$ It has also been found to be superior to oral astemizole in SAC. ${ }^{96}$

Until recently, topical formulations of antihistamines which were developed primarily for systemic administration, although having some beneficial effects, were usually not potent enough for monotherapy, and had to be administered with vasoconstrictors. ${ }^{97}$ However, levocabastine, ${ }^{98}$ developed for topical administration, acts within 10 minutes, ${ }^{99}$ has a high speed binding affinity for histamine $\mathrm{H} 1$ receptors, but does not interact with cholinergic receptors ${ }^{100-102}$ and has few systemic side effects. It is effective when given alone, is as effective as a vasodilator antihistamine combination for the treatment of SAC, ${ }^{103}$ and more effective than either placebo $^{104}$ or sodium cromoglycate in SAC. ${ }^{105}$ In double blind trials it has been found to be at least as effective as oral terfanidine, ${ }^{106} 107$ and on days when there was a high pollen count, was demonstrated to be more effective than oral terfanidine $e^{106} 107$ and topical sodium cromoglycate in relieving the symptoms of SAC. ${ }^{104}$

Several promising drugs are under development for the treatment of allergic eye disease, but have not yet been released. Of the new generation of $\mathrm{H}_{1}$ receptor antagonists, topical azelastine has been shown to be a powerful topical antihistamine, decreasing eosinophils and $\mathrm{T}$ lymphocyte activation. ${ }^{108}$ It both reduces and prevents the symptoms of SAC, ${ }^{109}$ but does not appear to reach maximal activity for 7 days. ${ }^{110}$ It acts on all types of inflammatory cells as well as reducing adhesion molecule expression. ${ }^{109}$

Loteprednol, a so called soft steroid, is effective in SAC prophylaxis ${ }^{111}$ and GPC treatment, ${ }^{112-114}$ but it can cause an intraocular pressure rise. ${ }^{115}$ Rimexoline is effective in the treatment of uveitis ${ }^{116}$ and so has a potential, so far untested, for allergic eye disease treatment. Another drug under development for ocular use is olopotadine, which is both a selective $\mathrm{H}_{1}$ receptor and an inhibitor of mast cell release. ${ }^{84117}$

Thus, the suggested treatment regimen of SAC and PAC, both of which are mast cell dependent, is for topical histamine $\mathrm{H}_{1}$ antagonists and mast cell stabilisers sodium cromoglycate, lodoxamide, nedocromil, or levocabastine, two to four times daily to be administered while symptoms last. If this treatment is insufficient to control the symptoms, then vasoconstrictors or oral antihistamines can be added. Alternatively, lubricants such as hypromellose will act to irrigate the eye and wash out tear histamine and other inflammatory mediators, thus diluting their effects and aiding the patient's comfort.

In the $\mathrm{T}$ cell dependent $\mathrm{AKC}$ and VKC, the existing mast cell stabiliser sodium cromoglycate has been used prophylactically or as maintenance therapy to control mild symptoms only, but is ineffective in acute exacerbations. In these conditions, the new mast cell stabilisers, such as lodoxamide ${ }^{79} 80$ and nedocromil,${ }^{90}{ }^{93}$ have been found to be effective, but steroids (dexamethasone) in doses up to one drop hourly, may still be required if these drugs are not sufficient to control the disease process, especially if a keratopathy is present. Topical cyclosporin, an anti-CD4+ cell agent, has been found to control the symptoms of $\mathrm{VKC},{ }^{118}$ but is not generally available. Topical lubricants may help in diluting the tears whose $\mathrm{pH}$ is abnormal as a result of the released cytokines and histamine.

In cases where corneal involvement occurs, particularly in VKC with corneal ulcers in the visual axis, the ulcers need to be debrided quickly to prevent scarring and the onset of amblyopia. Topical antibiotics may be added to the intensive topical steroid regimen while ulceration lasts.

In $\mathrm{AKC}$ and $\mathrm{ABC}$ strict attention should be paid to lid toilet in order to reduce lid crusting and possible staphylococcal colonisation of the lid, but the exact role of staphylococci in these conditions is uncertain. ${ }^{69}$ If blepharomeibomianitis is severe, then systemic oxytetracycline, $250 \mathrm{mg}$ twice a day for a month, may be needed, particularly if it is associated with a punctate keratopathy. Unless the latter is treated rigorously, this can develop into permanent corneal scarring and visual loss.

For GPC, removal of the allergen such as a contact lens, if necessary coupled with a mast cell stabiliser, will be sufficient.

\section{Future trends}

Future work needs to be directed at increasing our understanding of the genetics and workings of the cytokine repertoire of mast cells and $\mathrm{T}$ lymphocytes, the regulation of adhesion molecule expression, and B cell regulation of $\operatorname{IgE}$ secretion. As more allergens are identified, their complex structure needs to be defined, in order to identify that part, or epitope, of the allergen stimulating the allergic response.

With this knowledge, more ways of treating allergic eye disease will be developed, including more effective mast cell stabilisers and antihistamines, agents to antagonise adhesion molecules and reduce the production of allergen specific IgE, and, eventually, provide therapies which are able to downregulate the allergic response, rather than control its effects.

Many important questions remain unanswered. For example, it is unclear what determines whether a person suffers from SAC which is non-sight threatening, or from AKC, which is. Further work on the genetic analysis of allergic eye disease is required, and is possible with the new analytical tools now available.

This work was supported by grants from the Medical Research Council, the Jules Thorne Trust and the Wessex Medical School Trust, to whom many and very grateful thanks are given. Thanks also to Miss Lynn Key for help in typing this manuscript.

J I MCGILL S T HOLGATE $M$ K CHURCH D F ANDERSON

Southampton University Hospitals, Southampton General Hospital, Southampton

A BACON

Reading General Hospital and Moorfields Eye Hospital, London

Blackley CH. Experimental researches on the causes and cure of catarrhous aestivus (hay fever or asthma). Ballieri. London: Tindall and Cox, 1873:77.

Peat JK, van den Berg RH, Green WF, et al. Changing prevalence of asthma Peat JK, van den Berg RH, Green WF, et al. Chang

Fleming DM, Crombie DL. Prevalence of asthma and hay fever in England and Wales. BMF 1987;294:279-83.

4 Varjonen E, Kalimo K, Lammintausta K, et al. Prevalence of atopic disorder amongst adolescents in Turkh Finland. Allergy 1992;47:243-8

5 Weeke ER. Epidemiology of hay fever and perennial allergic rhinitis. Monogr Allergy 1987;21:1-20.

6 Peat JK, Haby M, Spijker J, et al. Prevalence of asthma in adults in Busselton, Western Australia. BMF 1992;305:1326-9.

Friedlaender $\mathrm{MH}$, Okumoto Y, Kelley J. Diagnosis of allergic conjunctivitis. Arch Ophthalmol 1984;102:1198-9.

8 Dart JKG. Eye disease at a community health centre. BMF 1986;293:1477-

Ehlers WH, Donshik PL. Allergic ocular disorders; a spectrum of diseases. $C L A O \mathcal{F} 1992 ; 117-24$.

10 Friedlaender MH. Conjunctivitis of allergic origin; clinical presentation and differential diagnosis. Surv Ophthalmol 1993 (suppl);38:105-14.

1 Allansmith MR, Ross RN. Ocular allergy. Clinical Allergy 1988;18:1-13.

12 Sheldrick J, Vernon SA, Wilson A, et al. The incidence and episode rates of ophthalmic disease in the general population. BMF 1992;305:933-6. 
13 Varney V. Hay fever in the United Kingdom. Clin Exp Allergy 1991;21:75762.

14 Dart JKG, Buckley RJ, Monnickendan M, et al. Perennial allergic conjunctivitis; definition, clinical characteristics and prevalence. Trans Ophthalmic Soc UK 1986;105:513-20.

15 Tuft SJ, Kemeny MD, Dart JKG, et al. Clinical features of atopic keratoconjunctivitis. Ophthalmology 1991;98:150-8.

16 Foster CS, Calonge MD. Atopic keratoconjunctivitis. Ophthalmology 1990;97:992-1000.

17 Bacon AS, Tuft SJ, Metz DM, et al. The origin of keratopathy in chronic allergic eye disease: a histopathological study. Eye 1993;7(suppl):21-5.

18 Garrity JA, Liesegang TJ. Ocular complications of atopic dermatitis. Can $\mathcal{f}$ Ophthalmol 1984;19:21-4.

19 Beigelman MN. Vernal conjunctivitis. Los Angeles: University of Southern California Press, 1950

20 Tuft SJ, Dart JKG, Kemeny M. Limbal vernal keratoconjunctivitis: clinical characteristics and immunoglobulin $\mathrm{E}$ expression compared with palpebral vernal. Eye 1989;3:420-7.

21 Buckley RJ. Vernal keratopathy and its management. Trans Ophthalmol Soc UK 1981;101:234-8.

22 Allansmith MR, Korb DB, Greiner JV, et al. Giant papillary conjunctivitis in contact lens wearers. Am f Ophthalmol 1977;83:697-708.

23 O'Donnell BF, Foulds IS. Contact allergic dermatitis and contact urticaria due to topical ophthalmic preparations. Br 7 Ophthalmol 1993;71:740-1.

24 Allansmith MR, O'Connor GR. Immunoglobulins: structure, function and relation to the eye. Surv Ophthalmol 1970;14:367-402.

25 Foster CS, Rice BA, Dutt JE. Immunopathology of atopic keratoconjunctivitis. Ophthalmology 1991;98:1190-6.

26 Asrar AMA El, Geboes K, Missotton L, et al. Cytological and immunohistochemical study of the limbal form of vernal keratoconjunctivitis by the replica technique. Br $\mathcal{F}$ Ophthalmol 1987;71:867-72.

27 Metz DP, Bacon AS, Holgate ST, et al. Phenotypic characterisation of T-cells infiltrating the conjunctiva in chronic allergic eye disease. 7 Allergy Clin Immunol I996;98:686-96.

28 Metz DM, Bonini S, Lightman S. mRNA expression for interleukin-2 interleukin-5 in vernal keratoconjunctivitis. Invest Ophthalmol Vis Sci 1993; 34;772.

29 Baddeley SM, Bacon, McGill JI, et al. Mast cell distribution and neutral protease expression in acute and chronic allergic conjunctivitis. Clin Exp Allergy 1995;25:41-5.

30 Morgan SJ, Williams JH, Walls AF, et al. Mast cell numbers and staining characteristics in the normal and allergic human conjunctiva. $\mathcal{F}$ Allergy Clin Immunol 1991;87:111-16.

31 Morgan SJ, Williams JH, Walls AF, et al. Mast cell hyperplasia in atopic keratoconjunctivitis. An immunohistochemical study. Eye 1991;5:729-35.

32 Anderson DF, MacLeod JDA, Baddeley SM, et al. Seasonal allergic conjunctivitis is accompanied by increased mast cell numbers in the absence of leukocyte infiltration. Clin Exp Allergy 1997;27:1060-6.

33 MacLeod JDA, Anderson DF, Holgate ST, et al. Immunolocalisation of mast cell cytokines to mast cells in normal and allergic conjunctiva. Clin Exp Allergy 1997;27:1328-34.

34 Anderson DF, MacLeod JDA, Baddeley SM, et al. Conjunctival cells mast cells are heterogenous with respect to cytokine storage. Invest Ophthalmol Vis Sci 1997;38:S727.

35 Bacon AS, Baddeley SM, McGill JI, et al. Adhesion molecules and relationship to leukocyte levels in allergic eye disease. Invest Ophthalmol Vis Sci 1998;39:322-30.

36 Bacon AS, Baddeley SM, McGill JI, et al. The conjunctival cellular response to allergen challenge in seasonal allergic conjunctivitis. (In preparation)

37 Britten KM, Howarth PH, Roche WR. Immunohistochemistry of resin sections: a comparison of resin embedding techniques for small mucosal biopsies. Biotech Histochem 1993;68:271-80.

38 Proud D, Sweet J, Stein P, et al. Inflammatory mediator release on conjunctival provocation of allergic subjects with allergen. I Allergy Clin Immunol 1990;85:896-905.

39 Henriquez AS, Kenyon KR, Allansmith MR. Mast cell ultrastructure. Comparison in contact lens associated giant papillary conjunctivitis and vernal parison in contact lens associated giant papillary con
conjunctivitis. Arch Ophthalmol 1981;99:1266-72.

40 Irani A-M A, Butrus SI, Tabbara KF, et al. Human conjunctival mast cells: distribution of $\mathrm{MC}_{\mathrm{T}}$ and $\mathrm{MC}_{\mathrm{TC}}$ in vernal conjunctivitis and giant papillary distribution of $\mathrm{MC}_{\mathrm{T}}$ and $\mathrm{MC}_{\mathrm{TC}}$ in vernal conjunctivitis
conjunctivitis. $\mathcal{F}$ Allergy Clin Immunol 1990;86:34-40.

41 Levi-Schaffer F, Segal V, Shalit M. Effects of interleukins on conjunctival tissue type mast cells co-cultured with fibroblasts. Immunology 1991;72: 174-80

42 Abelson MB, Chambers WA, Smith LA. Conjunctival allergen challenge. A clinical approach to studying allergic conjunctivitis. Arch Ophthalmol 1990; 108:84-8.

43 Weeke B, Poulson LH. Diagnostic tests for allergy. In: Holgate ST, Church MK, eds. Allergy. London: Gower Medical Publishing, 1993:11.1-11.4.

44 Ballow M, Donshik PC, Mendelson L, et al. IgG specific antibodies to rye grass and ragweed pollen antigens in the tear secretions of patients with vernal conjunctivitis. Am f Ophthalmol 1983;95:161-8.

45 Allansmith M, Frick OL. Antibodies to grass in vernal conjunctivitis. $f$ Allergy 1963;34:535-43.

46 Church MK, Okayama Y, Bradding P. The role of the mast cell in acute and chronic allergic inflammation. In: Chignard $M$, Pretolani $M$, Renesto $P$, Vargaftig BB, eds. Cells and cytokines in lung infection. Ann NY Acad Sci 1994;725:13-21.

47 Allansmith MR, Ross RN. Ocular allergy and mast cell stabilizers. Surv Ophthalmol 1986;30:229-44

48 Church MK, Caulfield JP. Mast cell and basophil functions. In: Holgate ST, Church MK, eds. Allergy. London: Gower Medical Publishing 1993, chapter 5, 1-12.

49 Bradding P, Feather IH, Wilson S, et al. Immunolocalisation of cytokines in the nasal mucosa of normal and perennial rhinitis subjects. The mast cell as a source of IL-4, IL-5 and IL-6 in human allergic mucosal inflammation. $₹$ Immunol 1993;151:3853-65.

50 Okayama Y, Semper A, Holgate ST, et al. Multiple cytokine mRNA expression in tissue mast cells stimulated via FcaR1. Int Arch Allergy Immunol 1995;107:158-9.

51 Walsh LJ, Trinchieri G, Waldorf HA, et al. Human dermal mast cells contain leukocyte adhesion molecule 1. Proc Natl Acad Sci USA 1991;88:4220-4.
52 Durham SR, Ying S, Varney VA, et al. Cytokine messenger RNA expression of IL-3, IL-4, Il-5 and granulocyte/macrophage-colony-stimulating factor
in the nasal mucosa after local allergen provocation: relationship to tissue in the nasal mucosa after local allergen pro

53 Ryan JJ. Interleukin-4 and its receptor: essential mediator of the allergic response. F Allergy Clin Immunol ACI 1997;99:1-5.

54 Meininger CJ, Yanoh H, Rottapel R, et al. The c-kit receptor ligand functions as a mast cell chemoattractant. Blood 1992;79:958-63.

55 Zhang S, Anderson DF, Bradding P, et al. Human mast cell expresses stem cell factor. F Path 1998; (in press).

56 Trocme SD, Kephart GM, Allansmith MR, et al. Conjunctival deposition of eosinophil major basic protein in vernal keratoconjunctivitis and contact lens-associated giant papillary conjunctivitis. Am f Ophthalmol 1989;108: 57-63.

57 Trocme SD, Kephart G, Bourne WM, et al. Eosinophil major basic protein deposition in human corneal shield ulcers Invest Ophthalmol Vis Sci 1992; S33:984.

58 Allansmith MR, Greiner JV, Baird RS. Number of inflammatory cells in the normal conjunctiva. Am $\mathcal{7}$ Ophthalmol 1978;86:250-9.

59 Abelson MB, Madiwale N, Weston JH. Conjunctival eosinophils in allergic ocular disease. Arch Ophthalmol 1983;101:555-6.

60 Horiuchi T. Studies on allergic conjunctivitis. Effects of neonatally injected oestrogen on experimental allergic conjunctivitis. Nippon Ganka Gakkai Zasshi (Acta Soc Ophthalmol Fap) 1970;74:803-8.

61 Horiuchi T. Studies of allergic conjunctivitis. Effects of neonatally injected androgen on experimental allergic conjunctivitis. Nippon Ganka Gakkai Zasshi (Acta Soc Ophthalmol fap) 1971;75:1524-30.

62 Schuurs AHWM, Verheul HAM. Effects of gender and sex steroids on the immune response. $\mathcal{F}$ Steroid Biochem 1990;35:157-72.

63 Tchernitchin AN, Barrera J, Arroyo P, et al. Degranulatory action of estradiol on blood eosinophil leukocytes in vivo and in vitro. Agents Actions 1985;17:60-6.

64 Bonini S, Lambiase A, Schiavone M, et al. Oestrogen and progesterone receptors in the human allergic conjunctivitis. ACI News 1994;suppl 2;14.

65 Mosmann TR, Coffman RL. TH1 and TH2 cells: different patterns of lymphokine secretion lead to different functional properties. Anпu Rev Immunol 1989;7:145-73.

66 Gleich GJ, Adolphson CR, Leiferman KM. The biology of the eosinophilic leukocyte. Annu Rev Med 1993;44:85-101.

67 Benyon RC, Lowman MA, Church MK. Human skin mast cells: their dispersion, purification and secretory characterisation. F Immunol 1987;138: 861-7.

68 Hartmann CT, Glousky MM. Complement activation requirements for histamine release from human leukocytes: influence of purified C3a $\mathrm{a}_{\text {hu }}$ and C5 $\mathrm{a}_{\text {hu }}$ on histamine release. Int Arch Allergy Appl Immunol 1981;66:274-81.

69 Tuft SJ, Ramikrishnan M, Seal DV, et al. Role of Staphylococcus aureus in chronic allergic conjunctivitis. Ophthalmology 1992;99:180-4.

70 Church MK, Norn S, Pow GJ-K, et al. Non IgE dependent bacteria induced histamine release from human lung and tonsillar mast cells. Clin Allergy 1987;17:341-53.

71 Pipkorn U, Katsson G, Enerback L. The cellular response of the human allergic mucosa to natural allergen exposure. $\mathcal{F}$ Allergy Clin Immunol 1988; 82:1046-54

72 Frew AJ, Kay AB. Eosinophils and T lymphocytes in late phase allergic reactions. F Allergy Clin Immunol 1989;85:533-9.

73 Abelson MB, Schaefer K. Conjunctivitis of allergic origin: immunologic mechanisms and current approaches to therapy. Surv Ophthalmol 1993;38: 115-32.

74 Simons FER. $\mathrm{H}_{1}$-receptor antagonists. Clinical pharmacology and therapeutics. F Allergy Clin Immunol 1989;84:845-61.

75 Bartlett JD. Management of allergic conjunctivitis. Ophthalmology 1997;104: 345-346.

76 Parrish RW, Davies BH. Inhalation challenge with specific grass pollen antigens in asthmatics and the effect of lodoxamide tromethamine. Thorax 1983;38:458-62.

77 Bonini S, Schiavone M, Bonini S, et al. Efficacy of lodoxamide eye drops on mast cells and eosinophils after allergen challenge in allergic conjunctivitis. Ophthalmology 1997;104:849-53.

78 Fahy GT, Easty DL, Collum LMT, et al. Double masked efficacy and safety evaluation of lodoxamide $0.1 \%$ ophthalmic solution versus opticrom $2 \%$ - a multicentre study. In: Ferrag de Oliveira LN, ed. Ophthalmology today. Amsterdam: Elsevier Science, 1988:341-2.

79 Fahy GT, Easty DL, Collum LMT, et al. Randomised double-masked trial of lodoxamide and sodium cromoglycate in allergic eye disease. A multicenter study. Eur $\mathcal{F}$ Ophthalmol 1992;2:144-9.

80 Verin PH, Verstappen A, Parsons D, et al. Potential for safer management of vernal kerato-conjunctivitis with lodoxamide $0.1 \%$ ophthalmic solution (Alomide). Proceedings of the 26th Congress of Ophthalmology, Singapore 1990.

81 Santos CI, Huang AK, Abelson MB, et al. Efficacy of lodoxamide 0.1\% ophthalmic solution in resolving corneal epitheliopathy associated with vernal kerato-conjunctivitis. Am $\mathcal{f}$ Ophthalmol 1994;117:488-97.

82 Pearce FL, Al-Laith M, Bosman L, et al. Effects of sodium cromoglycate and nedocromil sodium on histamine secretion from mast cells from various locations. Drugs 1989;37 (suppl):37-43.

83 Okayama Y, Benyon RC, Rees PH, et al. Inhibition profiles of sodium cromoglycate and nedocromil sodium on mediator release from mast cells of human skin, lung, tonsil, adenoid and intestine. Clin Exp Allergy 1992;22: 401-9.

84 Yanni JM, Miller ST, Gamache DA, et al. Comparative effects of topical ocular anti-allergy drugs on human conjunctival mast cells. Ann Allergy Asthma Immunol 1997;79:541-5.

85 Bruinjnzeel PPLB, Warringa RAJ, Kok PTM, et al. Inhibition of neutrophil and eosinophil induced chemotaxis by nedocromil sodium and sodium cromoglycate. Br F Pharmacol 1990;99:798-802.

86 Moqbel R, Cromwell O, Walsh GM, et al. The effects of nedocromil sodium (Tilade) on activation of human eosinophils, neutrophils and histamine release from mast cells. Allergy 1988;43:268-76.

87 Thorel T, Joseph M, Tsicopoulos A, et al. Inhibition by nedocromil sodium of IgE-mediated activation of human mononuclear phagocytes and of IgE-mediated activation of human mononuclear phagocyte

88 Fuller RW, Macdermot J. Stimulation of IgE sensitized human alveolar macrophages by anti-IgE is unaffected by sodium cromoglycate. Clin Exp Allergy 1986;16:523-6. 
89 Blumenthal M, Casale T, Dockhorn R, et al. Efficacy and safety of nedocromil sodium ophthalmic solution in the treatment of seasonal allergic conjunctivitis. Am f Ophthalmol 1992;113:56-63.

90 Stockwell A, Easty DL. Group comparative trial of $2 \%$ nedocromil sodium with placebo in the treatment of seasonal allergic conjunctivitis. Eur f Ophthalmol 1994;4:19-23.

91 Van Bijsterveld OP, Kempeneers HP, Moons A, et al. A double-blind group comparative study of $2 \%$ nedocromil sodium and placebo in the treatment of perennial allergic conjunctivitis. Ocular Immunol Inflamm 1994;2:17786.

92 Bailey CS, Buckley RJ. Nedocromil sodium in contact-lens-associated papillary conjunctivitis. Eye 1993;7(suppl):29-33.

93 Bonini S, Barney NP, Schiavone M, et al. Effectiveness of nedocromil sodium $2 \%$ eye drops on clinical symptoms and tear fluid cytology of patients with vernal conjunctivitis. Eye 1992;6:648-52.

94 El Hennawi M. A double-blind group comparative study of nedocromil sodium $2 \%$ ophthalmic solution, $2 \%$ sodium cromoglycate eye drops and placebo eye drops in the treatment of vernal keratoconjunctivitis. $\mathrm{Br} \mathcal{F} \mathrm{Oph}$ placebo eye drops in the

95 Leino M, Ennevaara K, Latvala A-L, et al. Double-blind group comparative study of $2 \%$ nedocromil sodium eye drops with $2 \%$ sodium cromoglycate and placebo eye drops in the treatment of seasonal allergic conjunctivitis. and placebo eye drops in the treat

96 Miglior M, Scullica L, Secchi AG, et al. Nedocromil sodium and astemizole, alone or combined, in the treatment of seasonal allergic conjunctivitis. A multicentre double-blind clinical trial. Acta Ophthalmol 1993;71:73-8.

97 Abelson MB, Paradis A, George MA, et al. Effects of Vasocon-A in the allergen challenge model of acute allergic conjunctivitis. Arch Ophthalmol 1990, 108:520-4.

98 Dechant KL, Goa KL. Levocabastine. A review of its pharmacological properties and therapeutic potential as a topical antihistamine in allergic rhinitis and conjunctivitis. Drugs 1991;41:202-24.

99 Stokes TC, Feinburg G. Rapid onset of action of levocabastine eye-drops in histamine-induced conjunctivitis. Clin Exp Allergy 1993;23:791-4.

100 Pécoud A, Zuber P, Kolly M. Effect of a new selective $\mathrm{H}_{1}$ receptor antagonist (Levocabastine) in a nasal and conjunctival provocation test. Int Arch Allergy Appl Immunol 1987;82:541-3.

101 Abelson MB, Smith LM. Levocabastine. Evaluation in the histamine and compound $48 / 80$ models of ocular allergy in humans. Ophthalmology 1988 ; 95;1494-7.

102 Palma-Carlos AG, Palma-Carlos ML, Rombaut N. The effect of levocabastine nasal spray in provocation tests. Int f Clin Pharm Res 1988;8; 25-30.

103 Abelson MB, George MA, Schaefer K, et al. Evaluation of the new ophthalmic antihistamine $0.05 \%$ levocabastine in the clinical allergen challenge model of allergic conjunctivitis. F Allergy Clin Immunol 1994;94:458-64.
104 Azevdo M, Castel-Branco MG, Ferrez Oliveira J, et al. Double-blind comparison of levocabastine eye drops with sodium chromoglycate and placebo
in the treatment of seasonal allergic conjunctivitis. Clin Exp Allergy in the treatment

105 Davies BH, Mullins J. Topical levocabastine is more effective than Sodium Chromoglycate for the prophylaxis and treatment of seasonal allergic conjunctivitis. Allergy 1993;48:519-24.

106 Sfhoel P, Freng BA, Kramer J, et al. Topical levocabastine compared with orally administered terfanidine for the prophylaxis and treatment of seasonal allergic rhinoconjunctivitis. F Allergy Clin Immunol 1993;92:73-81.

107 The Livostin Study Group. A comparison of topical levocabastine and oral terfanidine in the treatment of allergic rhinoconjunctivitis. Allergy 1993;48: $530-4$.

108 Hoshino M, Nakamura Y. The effect of azelastine on the infiltration of inflammatory cells into the bronchial mucosa and clinical changes in patients with bronchial asthma. Int Arch Allergy Immunol 1997;114:285-92.

109 Ciprandi G, Buscalagia S, Catrullo A, et al. Azelastine eye drops reduce and prevent allergic conjunctival reaction and exert anti-allergic activity. Clin Exp Allergy 1996;27:182-91.

110 Lenhard G, Mivsek-Music E, Perrin-Fayolle $M$, et al. Double-blind, randomised, placebo-controlled study of two concentrations of azelastine randomised, placebo-controlled study of two concentrations of azelastine Med Res Opin 1997;14:21-8.

111 Dell SJ, Shulman DG, Lowry GM, et al. A controlled evaluation of the efficacy and safety of loteprednol etabonate in the prophylactic treatment of seasonal allergic conjunctivitis. Am f Ophthalmol 1997;123:791-7.

112 Bartlett JD, Howes JF, Ghormley NR, et al. Safety and efficacy of loteprednol etabonate for treatment of papillae in contact lens-induced giant papillary conjunctivitis. Curr Eye Res 1993;12:312-21.

113 Friedlaender $\mathrm{MH}$, Howes J. A double-masked, placebo controlled evaluation of the efficacy and safety of loteprednol etabonate in the treatment of giant papillary conjunctivitis. The Loteprednol Etabonate Giant Papillary Conjunctivitis Study Group 1. Am f Ophthalmol 1997;123:455-64.

114 Asbell P, Howes J. A double-masked placebo-controlled evaluation of the efficacy and safety of loteprednol etabonate in the treatment of giant papillary conjunctivitis. $C L A O \mathcal{7} 1997 ; 23: 31-6$.

115 Bartlett JD, Horwitz B, Howes J. Intraocular pressure response to loteprednol etabonate in known steroid responders. F Ocul Pharmacol 1993;9:157-65.

116 Foster CS, Alter G, DeBarge LR, et al. Efficacy and safety of rimexolone $1 \%$ ophthalmic suspension vs $1 \%$ prednisolone acetate in the treatment of uveitis. Am ₹ Ophthalmol 1996;122:171-82.

117 Sharif NA, Xu SX, Miller ST, et al. Characterization of the ocular antiallergic and antihistaminc effects of olopatadine (AL-4943A), a novel drug for treating ocular allergic diseases. F Pharmacol Exp Ther 1996;278:1252-61

118 Bleik JH, Tabbara KF. Topical cyclosporin in vernal keratoconjunctivitis. Ophthalmology 1991;98:1679-84. 